\title{
Genetic variation for seed yield components of Westerwold ryegrass (Lolium multiflorum var. westerwoldicum)
}

\author{
A. ELGERSMA, A. P. M. DEN NIJS \& F. A. VAN EEUWIJK \\ Foundation for Agricultural Plant Breeding (SVP), P.O. Box 117, NL 6700 AC Wagenin- \\ gen, Netherlands
}

Received 17 November 1988; accepted 7 February 1989

\begin{abstract}
Genetic variation for seed yield components was studied in four diploid varieties of Westerwold ryegrass. Per variety, 19 genotypes were grown in the field in two clonal replicate rows (minirows). We determined the number of inflorescences per minirow, the number of spikelets per inflorescence and florets and seeds per spikelet, 1000-grain weight and seed yield per minirow. Floret site utilization (FSU) was calculated as (seeds/florets) $\times 100 \%$. Genotypic variation and heritabilities were calculated. Correlation studies and path analyses were carried out in each variety separately. Among varieties, no significant differences occurred for seed yield. However, within varieties large genetic variation was present for both seed yield and yield components. Path analyses revealed, that relationships between seed yield components differed to a great extent among varieties. FSU was the major yield component in three varieties, but in one variety, inflorescence number was the most important yield component. There was ample opportunity for genetic improvement of seed yield. FSU had a very high heritability and was not correlated with any of the other seed yield components.
\end{abstract}

Keywords: Lolium multiflorum, Westerwold ryegrass, seed production, breeding, path analysis, genetic variation

\section{Introduction}

Grasses are grown for vegetative production, so plant breeders have selected varieties with excellent forage or turf qualities, but have given limited attention to seed production. Seed yields in grasses are low and unpredictable. Cultivars can only be commercialized, if the seed production is satisfactory. Therefore, seed yield should become a more important selection criterion in grass breeding (Elgersma, 1985).

Westerwold ryegrass, Lolium multiflorum var. westerwoldicum, is used for green manure. In the literature, we have found no information about genetic variation for seed production in this annual species. In order to improve the selection efficiency for seed production, information is required on the components of seed yield and their influence on total seed yield. 
Therefore, this study intends to estimate genetic variation for seed yield and yield components in Westerwold ryegrass.

\section{Materials and methods}

Four diploid varieties of Lolium multiflorum Lam. var. westerwoldicum were used: 'Wewo', 'Weldra', 'Merwester' and 'Baroldi'. Diploid varieties were chosen because they offer the best opportunity for genetic studies and selection experiments. Seeds were sown in a cool greenhouse $\left(4-10^{\circ} \mathrm{C}\right)$ on December 1984 . Per variety, 19 randomly chosen plants were cloned into ten ramets. The experimental field was established during the first week of May on a sandy soil near Wageningen, the Netherlands. The experimental field was surrounded by a border row, sown on the planting date.

Per genotype, two experimental units were obtained by planting five clonal ramets very closely together in a minirow of $0.25 \mathrm{~m}$ length. In this way a drilled plot was simulated, although rows were rather widely spaced $(0.5 \mathrm{~m})$. The experimental design consisted of two randomized blocks. A fertilization was given in May and weeds were rogued mechanically. Plants were kept upright during flowering and ripening.

Per experimental unit, five representative inflorescences were collected approximately two weeks after anthesis, before shedding had begun. The number of spikelets (SPKL) per inflorescence was determined. We randomly chose three out of these five inflorescences and counted the number of florets (FL) and seeds in each spikelet. It proved too laborious to collect these data on all five inflorescences. Biological floret site utilization (FSU) was calculated per inflorescence as (seeds/florets $) \times 100 \%$ (Elgersma, 1985). Per experimental unit the remaining inflorescences were harvested when the average was ripe. The number of mature inflorescences (INFL), seed yield (Y) and 1000-grain weight (TGW) were determined.

Within each variety, analyses of variance were conducted. Means, phenotypic, genotypic and environmental variances and coefficients of variation and wide-sense heritabilities were calculated for each character. No analysis of variance was conducted among varieties, because variances were rather heterogeneous. Instead, we tested the significance of pairwise differences between means of varieties using a $t$ test. Phenotypic, genotypic and environmental correlation coefficients were calculated between characters. Path analysis was applied for further analysis of the genotypic correlations (Wright, 1982; Li, 1975). The relationship between seed yield and yield components is multiplicative: $\mathrm{Y}=\mathrm{INFL} \times \mathrm{SPKL} \times \mathrm{FL} \times \mathrm{FSU} \times \mathrm{TGW}$. Path models assume that the relationships among the variables are linear and additive. Therefore, data were logtransformed to obtain an additive relationship.

\section{Results}

Heading started in the beginning of June and flowering approximately in the third week of June. Within inflorescences as well as among inflorescences within experimental units, a great spread in flowering time was observed. Harvest ripeness oc- 
Table 1. Mean values, ranges, phenotypic $\left(c v_{\mathrm{p}}\right)$ and genotypic $\left(c v_{\mathrm{g}}\right)$ coefficients of variation $(\%)$ and heritabilities $\left(h^{2}\right)$ of five seed yield components and seed yield per minirow in four varieties of Westerworld ryegrass.

\begin{tabular}{llllll}
\hline Variety & mean & range & $c v_{\mathrm{p}}$ & $c v_{\mathrm{g}}$ & $h^{2}$
\end{tabular}

Number of inflorescences per minirow

$\begin{array}{llllll}\text { Wewo } & 125 \mathrm{a}^{1} & 31-195 & 32 & 27 & 0.74 \\ \text { Weldra } & 132 \mathrm{a} & 46-215 & 26 & 23 & 0.79 \\ \text { Merwester } & 137 \mathrm{a} & 79-231 & 30 & 16 & 0.33 \\ \text { Baroldi } & 141 \mathrm{a} & 62-175 & 19 & 14 & 0.57\end{array}$

Number of spikelets per inflorescence

$\begin{array}{lrrrrr}\text { Wewo } & 21.1 \mathrm{a} & 19.2-23.5 & 8 & 8 & 0.84 \\ \text { Weldra } & 20.8 \mathrm{a} & 17.4-25.1 & 9 & 8 & 0.79 \\ \text { Merwester } & 19.7 \mathrm{a} & 15.6-24.6 & 12 & 11 & 0.87 \\ \text { Baroldi } & 22.6 \mathrm{~b} & 18.1-27.3 & 10 & 9 & 0.89\end{array}$

Number of florets per spikelet

$\begin{array}{lrrrrr}\text { Wewo } & 10,0 \mathrm{~b} & 8.1-11.8 & 9 & 8 & 0.67 \\ \text { Weldra } & 9.8 \mathrm{~b} & 7.3-12.4 & 13 & 12 & 0.88 \\ \text { Merwester } & 8.5 \mathrm{a} & 5.7-10.6 & 15 & 14 & 0.76 \\ \text { Baroldi } & 9.5 \mathrm{~b} & 8.1-11.6 & 12 & 10 & 0.77\end{array}$

Floret site utilization (\%)

$\begin{array}{llllll}\text { Wewo } & 74.1 \mathrm{a} & 47.0-91.0 & 13 & 13 & 0.95 \\ \text { Weldra } & 74.8 \mathrm{a} & 45.2-87.3 & 15 & 14 & 0.97 \\ \text { Merwester } & 67.3 \mathrm{a} & 26.8-85.5 & 27 & 26 & 0.91 \\ \text { Baroldi } & 72.5 \mathrm{a} & 58.2-85.7 & 12 & 11 & 0.93\end{array}$

Thousand-grain weight $(g)$

$\begin{array}{lllrrr}\text { Wewo } & 3.43 \mathrm{~b} & 2.72-4.06 & 12 & 11 & 0.88 \\ \text { Weldra } & 3.22 \mathrm{ab} & 2.71-3.97 & 10 & 9 & 0.84 \\ \text { Merwester } & 3.12 \mathrm{a} & 2.66-3.78 & 10 & 10 & 0.98 \\ \text { Baroldi } & 3.21 \mathrm{ab} & 2.31-4.19 & 14 & 13 & 0.92\end{array}$

Seed yield per minirow $(g)$

$\begin{array}{llllll}\text { Wewo } & 42.0 \mathrm{a} & 23.8-58.8 & 25 & 17 & 0.43 \\ \text { Weldra } & 45.2 \mathrm{a} & 28.5-68.4 & 21 & 18 & 0.70 \\ \text { Merwester } & 40.5 \mathrm{a} & 10.6-60.4 & 35 & 32 & 0.87 \\ \text { Baroldi } & 42.0 \mathrm{a} & 22.2-62.3 & 29 & 28 & 0.92\end{array}$

${ }^{1}$ Values within a column followed by the same letter do not significantly differ according to the $t$-test $(P \leqslant 0.05)$.

curred in the first week of August.

Means, ranges, phenotypic and genotypic coefficients of variation and widesense heritabilities are presented in Table 1.

For the number of inflorescences per experimental unit no significant differences occurred among varieties, although 'Wewo' had rather few inflorescences. In 
'Wewo' and 'Weldra', large genotypic variation $\left(c v_{\mathrm{g}}=27\right.$ and $23 \%$, respectively) and rather high heritabilities were found for inflorescence number $\left(h^{2}=0.74\right.$ and 0.79 , respectively). In 'Merwester', heritability was low $\left(h^{2}=0.33\right)$, due to a large environmental variation $\left(c v_{\mathrm{e}}=23 \%\right)$.

The number of spikelets per inflorescence of 'Baroldi' was significantly higher than in other varieties. 'Merwester' had a rather low number of spikelets per inflorescence (19.7). Coefficients of genotypic variation ranged from 8 to $14 \%$.

The number of florets per spikelet was significantly lower in 'Merwester' (8.5) than in the other varieties $(9.5$ to 10.0$)$. Coefficients of genotypic variation ranged from 8 to $14 \%$.

Although 'Merwester' had a slightly lower FSU than the other varieties, no significant differences among varieties were found. 'Merwester' had the highest genotypic variation $\left(c v_{\mathrm{g}}=26 \%\right)$. Generally, the heritability for FSU was very high since there was almost no environmental variation associated with this trait.

Thousand-grain weight in 'Wewo' was significantly higher $(3.43 \mathrm{~g})$ than in 'Merwester' $(3.12 \mathrm{~g})$.

No significant differences among varieties were found for seed yield per minirow. Genotypic variation was highest in 'Merwester $\left(c v_{\mathrm{g}}=32 \%\right)$. The heritability for seed yield was rather low in 'Wewo' $\left(h^{2}=0.43\right)$.

There was large genotypic variation for seed yield and number of inflorescences. Heritabilities were very high for FSU and rather high for spikelet number and 1000grain weight. Heritabilities for inflorescence number and seed yield differed greatly among varieties, but due to the large confidence-intervals, these differences were never significant (Table 1).

Genotypic correlation coefficients between seed yield components are presented in Table 2.

In general, there was a close agreement between phenotypic and genotypic correlation coefficients, genotypic correlations tending to be somewhat higher. Throughout this paper, we shall refer only to genotypic correlations to avoid unnecessary repetitions.

A significant correlation between seed yield and FSU was found in 'Weldra', 'Merwester' and 'Baroldi'. In 'Wewo', seed yield was significantly correlated with inflorescence number and not with FSU. All other components were never significantly correlated with seed yield. In 'Weldra' and 'Baroldi', negative associations were found between inflorescence number and 1000-grain weight. In 'Weldra', 1000-grain weight was also negatively correlated with the number of florets per spikelet (Table 2).

In Table 3, path coefficients between seed yield per minirow and its components are presented. The positive correlation between inflorescence number and seed yield in 'Wewo' $\left(r=0.51^{*}\right)$ was largely caused by a direct effect $(0.53)$. In 'Merwester' the direct effect of inflorescence number on seed yield was slightly larger $(0.58)$, but due to negative indirect effects via spikelet $(-0.12)$ and floret numbers $(-0.12)$, the overall correlation was lower $(r=0.40)$.

No significant correlation was found between spikelet number and yield. The direct positive effect in 'Merwester' $(0.31)$ was masked by negative indirect effects. 
Table 2. Coefficients of genotypic correlation between seed yield components and with seed yield in four varieties of Westerwold ryegrass.

\begin{tabular}{lllll}
\hline 1 & 2 & 3 & 4 & 5 \\
INFL & SPKL & FL & FSU & TGW
\end{tabular}

Wewo

1 INFL

2 SPKL

$3 \mathrm{FL}$ $-0.13$

4 FSU

0.15

$-0.04$

$-0.28$

5 TGW

$-0.38$

$6 \mathrm{Y}$

$0.51^{*}$

$-0.34$

0.26

$-0.19$

0.15

0.24

0.40

0.32

Weldra

1 INFL

2 SPKL

$3 \mathrm{FL}$

4 FSU

$-0.38$

0.31

0.02

$0.44 \quad-0.31$

5 TGW

$-0.46^{*}$

0.09

0.11

$-0.17$

-0.03
$-0.91^{* *}$
-0.32

$-0.31$

$6 \mathrm{Y}$

Merwester

1 INFL

2 SPKL

$3 \mathrm{FL}$

$-0.37$

$-0.29$

0.09

$-0.02$

4 FSU

0.21

0.16

0.40

$-0.39$

0.24

5 TGW

0.19

0.15

0.02

0.42

$0.87^{* *}$

0.09

Baroldi

1 INFL

2 SPKL

$3 \mathrm{FL}$

$-0.05$

$-0.14$

$-0.40$

4 FSU

0.04

0.04

$-0.55^{*}$

$-0.14$

0.24

$6 \mathrm{Y}$

$-0.28$

0.02

$-0.41$

$-0.10$

$-0.30$

d.f. $=17$.

${ }^{*} P \leqslant 0.05,{ }^{* *} P \leqslant 0.01$.

$\mathrm{INFL}=$ number of inflorescences per minirow, $\mathrm{SPKL}=$ average number of spikelets per inflorescence, $\mathrm{FL}=$ average number of florets per spikelet, FSU $=$ average floret site utilization $(\%), \mathrm{TGW}=1000-$ grain weight $(\mathrm{g}), \mathrm{Y}=$ seed yield per minirow $(\mathrm{g})$.

No significant correlations between floret number and seed yield were found in any variety. In 'Weldra', a large direct effect of floret number was found (1.25), but this was masked by a large negative indirect effect of floret number via 1000 -grain weight $(-1.52)$.

Significant genotypic correlations between FSU and seed yield in 'Weldra' ( $r=$ $\left.0.56^{*}\right)$, 'Merwester' $\left(r=0.87^{* *}\right)$ and 'Baroldi' $\left(r=0.51^{*}\right)$ were mainly due to di- 


\section{A. ElgERSMA, A. P. M. DEN NIJS AND F. A. VAN EEUWIJK}

Table 3. Results of the path analyses of the variation in seed yield within four varieties of Westerwold ryegrass.

Wewo Weldra Merwester Baroldi

Number of inflorescences

$\begin{array}{lrrrr}\text { Direct effect } & 0.53 & -0.04 & 0.58 & 0.04 \\ \text { Indirect effect via: } & & & & \\ \text { SPKL } & -0.01 & 0.01 & -0.12 & -0.01 \\ \text { FL } & 0.04 & 0.38 & -0.13 & -0.01 \\ \text { FSU } & -0.01 & 0.49 & 0.06 & 0.03 \\ \text { TGW } & -0.04 & -0.74 & 0.00 & -0.35 \\ \text { Correlation }(r) & 0.51^{*} & 0.11 & 0.40 & -0.28\end{array}$

Number of spikelets per inflorescence

$\begin{array}{lrrrr}\text { Direct effect } & 0.04 & -0.03 & 0.31 & 0.10 \\ \text { Indirect effect via: } & & & & \\ \text { INFL } & -0.07 & 0.02 & -0.22 & -0.00 \\ \text { FL } & -0.07 & 0.03 & -0.09 & -0.02 \\ \text { FSU } & -0.11 & -0.34 & 0.11 & 0.03 \\ \text { TGW } & 0.03 & 0.16 & -0.00 & -0.09 \\ \text { Correlation }(r) & -0.19 & -0.17 & 0.19 & 0.02\end{array}$

Number of florets per spikelet

$\begin{array}{lrrrr}\text { Direct effect } & 0.26 & 1.25 & 0.43 & 0.05 \\ \text { Indirect effect via: } & & & & -0.01 \\ \quad \text { INFL } & 0.08 & -0.01 & -0.17 & -0.04 \\ \text { SPKL } & -0.01 & -0.00 & -0.01 & 0.16 \\ \text { FSU } & 0.05 & -0.03 & 0.16 & -0.26 \\ \text { TGW } & 0.02 & -1.52 & 0.00 & -0.10 \\ \text { Correlation }(r) & 0.40 & -0.32 & 0.42 & \end{array}$

Floret site utilization

\begin{tabular}{lrrrr} 
Direct effect & 0.33 & 1.12 & 0.67 & 0.68 \\
Indirect effect via: & & & & \\
$\quad$ INFL & -0.02 & -0.02 & 0.05 & 0.00 \\
SPKL & -0.01 & 0.01 & 0.05 & 0.00 \\
FL & 0.04 & -0.04 & 0.10 & 0.01 \\
$\quad$ TGW & -0.02 & -0.51 & 0.00 & -0.19 \\
Correlation $(r)$ & 0.32 & $0.56^{*}$ & $0.87^{* *}$ & $0.51^{*}$ \\
& & & & \\
Thousand-grain weight & & & & \\
Direct effect & 0.10 & 1.66 & 0.01 & 0.63 \\
Indirect effect via: & & & & -0.02 \\
$\quad$ INFL & -0.20 & 0.02 & 0.12 & -0.01 \\
SPKL & 0.01 & -0.00 & -0.12 & -0.02 \\
FL & 0.06 & -1.14 & 0.07 & -0.20 \\
$\quad$ FSU & -0.06 & -0.34 & 0.02 & 0.37 \\
Correlation $(r)$ & -0.09 & 0.20 & 0.09 & 0.56 \\
& & & & \\
$R^{2}$ & 0.46 & 0.55 & 1.06 & \\
\hline${ }^{*} P \leqslant 0.05, * * P \leqslant 0.01$. & & & &
\end{tabular}


rect effects $(1.12,0.67$ and 0.68 , respectively). In 'Weldra' and 'Baroldi' negative indirect effects via 1000 -grain weight occurred ( -0.51 and -0.19 , respectively). In 'Merwester', however, all indirect effects were positive, resulting in a high overall correlation.

Correlations between 1000 -grain weight and seed yield were not significant. Positive direct effects were found in 'Weldra' (1.66) and 'Baroldi' (0.63), but large negative indirect effects occurred via FSU ( -0.34 and -0.20 , respectively) and, in 'Weldra', also via floret number $(-1.14)$ (Table 3$)$.

The variation for seed yield components explained on average $50 \%$ of the variation in seed yield in three varieties. The $R^{2}$ for 'Merwester' was higher than 1 because of the estimation procedure used for the genetical variances and covariances. Although this is rather an artefact, one may still conclude that yield is very strongly determined by the above-mentioned seed yield components.

\section{Discussion}

Despite the lack of significant differences for seed yield per minirow between the four varieties, the varieties did differ significantly for three components of seed yield. Within each variety, extensive variation was found for seed yield as well as for yield components, and thus good opportunities for selection are present.

Several studies have been undertaken to determine the importance of seed yield components in grasses, e.g., Italian ryegrass (Bugge, 1981), perennial ryegrass Bugge, 1987), Kentucky bluegrass (van Wijk, 1985), crested wheatgrass (Dewey \& Lu, 1959), tall fescue (Nguyen \& Sleper, 1983; Ibrahim \& Frakes, 1984) and meadow fescue (Lewis, 1966). When path analysis is applied, generally much variation in seed yield remains unexplained, e.g. $65 \%$ and $74 \%$, respectively, in two meadow fescue varieties (Lewis, 1966), $40 \%$ in crested wheatgrass (Dewey \& Lu, 1959) and $75 \%$ and $93 \%$ in Kentucky bluegrass populations during two successive years (van Wijk, 1985). Obviously, in those studies seed yield was influenced by factors other than the yield components. In our experiment, in three varieties about $50 \%$ of the variation in seed yield was explained, and in one variety all variation was explained. This increased accuracy in determining the relations between the components of seed yield may stem from the minirow design of clonal ramets which we used.

In 'Wewo', the number of inflorescences was the most important yield component. This variety also had the lowest number of inflorescences, indicating that in 'Wewo' inflorescence number may be a limiting factor for high seed yield. Bugge (1981) did not find a relation between seed yield and the number of inflorescences produced by single plants in pots. In sown plots, however, significant relationships between inflorescence number and seed yield were found (unpublished results mentioned in Bugge, 1987). Therefore, inflorescence number and its relationship to seed yield probably depend on the experimental growing conditions, i.e., pots, spaced plants or drilled plots and observations may only be valid when applied to similar conditions. In our experiment, drilled plots were simulated by the minirows. In perennial ryegrass, spaced plants do not provide useful information on seed yield 
in sown plots (Elgersma, unpublished results). Breeding programs start with individual genotypes, which cannot be examined in sown plots. A drilled plot may be simulated by planting clonal ramets closely together. To provide sufficient compatible pollination, however, single rows are preferable to plots. Our impression was that the minirow design provided information that was more applicable to the situation in practice than spaced plants would have provided.

Of all yield components, inflorescence number was affected most strongly by the environment in Italian ryegrass (Bugge, 1981). In our experiment, only in one varity inflorescence number was the major component. FSU was the most important yield component in the other varieties. FSU is less influenced by experimental growing conditions than inflorescence number (e.g. Davies, 1954; Knowles \& Baenziger, 1962). Other authors have also emphasized the importance of FSU in various grass species, e.g. perennial ryegrass (Davies, 1954; Bugge, 1987), wheatgrass species (Knowles \& Baenziger, 1962; Dewey \& Lu, 1959; Slinkard, 1965) and bromegrass (Ross \& Adams, 1955; Nielson \& Kalton, 1959).

In practical seed growing, lodging may decrease both FSU and also seed shattering, which is an important yield-reducing factor in Westerwold ryegrass. In this experiment we were unable to measure shattering separately, but as minirows were individually observed and were harvested in time, we feel that seed shattering was of limited importance in our experiment.

We were able to detect genetic differences for FSU per se, i.e. not affected by the degree of lodging. Since FSU was not significantly correlated with other yield components and only a weak negative association was found with 1000 -grain weight in two varieties, selection for high FSU is expected to increase seed yield without adversely affecting other seed yield components. In a breeding programme, high FSU should be combined with reduced or retarded lodging and with shattering resistance to obtain a population with a high seed production level.

\section{Acknowledgements}

Technical assistance of Ir S. E. de Lange-Westra is gratefully acknowledged. We thank Dr O. Dolstra for useful suggestions and comments on the manuscript.

A. Elgersma thanks the Commodity Board for Arable Products for financial support.

\section{References}

Bugge, G., 1981. Genetic variability in the components of seed yield of ryegrass species. Report Meeting Fodder Crops Section Eucarpia: 17-32.

Bugge, G., 1987. Selection for seed yield in Lolium perenne L. Plant Breeding 98: 149-155.

Davies, E. W., 1954. 'Shift' in a late-flowering strain of perennial ryegrass (Lolium perenne). In: Proceedings European Grassland Conference, OECC,p. 102-106.

Dewey, D. R. \& K. H. Lu, 1959. A correlation and path-coefficient analysis of components of crested wheatgrass seed production. Agronomy Journal 51: 515-518.

Elgersma, A., 1985. Floret size utilization in grasses: definitions, breeding perspectives and methodology. Journal of Applied Seed Production 3: 50-54. 
Ibrahim, S. R. D. \& R. V. Frakes, 1984. Variability and interrelations of seed yield components in tall fescue ( $F$. arundinacea Schreb.). Genetica Agrarica 38: 387-398.

Knowles, R. P. \& H. Baenziger, 1962. Fertility indices in cross-pollinated grasses. Canadian Journal of Plant Science 42: 460-471.

Lewis, J., 1966. The relationship between seed yield and associated characters in meadow fescue (Festuca pratensis). Journal of Agricultural Science (Cambridge) 67: 243-248.

Li, C. C., 1975. Path analysis; a primer. The Boxwood Press, USA, 347 pp.

Nguyen, H. I. \& D. A. Sleper, 1983. Genetic variability of seed yield and reproductive characters in tall fescue. Crop Science 23: 621-626.

Nielson, A. K. \& R. R. Kalton, 1959. Combining ability for seed characteristics in Bromus inermis Leyss. Agronomy Journal 51: 178-181.

Ross, J. G. \& M. W. Adams, 1955. The influence of heredity on seed and forage production in smooth bromegrass. Proceedings of the South Dakota Academy of Science 34: 16-20.

Slinkard, A. E., 1965. Fertility in intermediate wheatgrass Agropyron intermedium (Host) Beauv. Crop Science 5: 363-365.

Wijk, A. J. P. van, 1985. Factors affecting seed yield in breeding material of Kentucky bluegrass (Poa pratensis L.). Journal of Applied Seed Production 3: 59-66.

Wright, S., 1921. Correlation and causation. Journal of Agricultural Research 20: 557-587. 